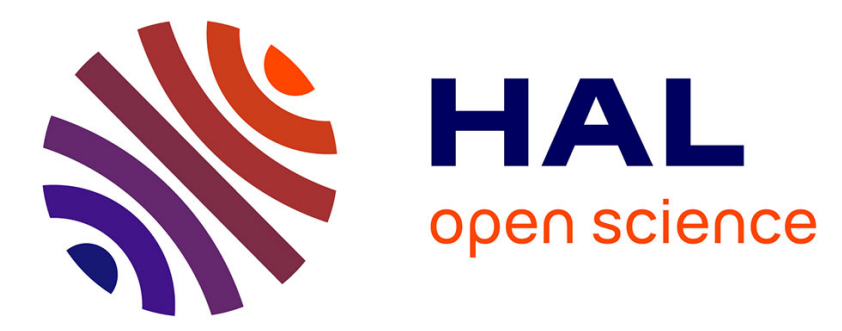

\title{
Genome analysis of Thermosulfuriphilus ammonigenes ST65T, an anaerobic thermophilic chemolithoautotrophic bacterium isolated from a deep-sea hydrothermal vent
}

Galina Slobodkina, Maxime Allioux, Alexander Merkel, Karine Alain, Mohamed Jebbar, Alexander Slobodkin

\section{To cite this version:}

Galina Slobodkina, Maxime Allioux, Alexander Merkel, Karine Alain, Mohamed Jebbar, et al.. Genome analysis of Thermosulfuriphilus ammonigenes ST65T, an anaerobic thermophilic chemolithoautotrophic bacterium isolated from a deep-sea hydrothermal vent. Marine Genomics, 2020, pp.100786. 10.1016/j.margen.2020.100786 . hal-02995863

\section{HAL Id: hal-02995863 \\ https://hal.science/hal-02995863}

Submitted on 16 Nov 2020

HAL is a multi-disciplinary open access archive for the deposit and dissemination of scientific research documents, whether they are published or not. The documents may come from teaching and research institutions in France or abroad, or from public or private research centers.
L'archive ouverte pluridisciplinaire HAL, est destinée au dépôt et à la diffusion de documents scientifiques de niveau recherche, publiés ou non, émanant des établissements d'enseignement et de recherche français ou étrangers, des laboratoires publics ou privés. 


\title{
Genome analysis of Thermosulfuriphilus ammonigenes ST65 ${ }^{\mathrm{T}}$, an anaerobic thermophilic chemolithoautotrophic bacterium isolated from a deep-sea hydrothermal vent
}

\author{
Galina Slobodkina ${ }^{\mathrm{a}, *}$, Maxime Allioux ${ }^{\mathrm{b}}$, Alexander Merkel ${ }^{\mathrm{a}}$, Karine Alain ${ }^{\mathrm{b}}$, Mohamed Jebbar ${ }^{\mathrm{b}}$, \\ Alexander Slobodkin ${ }^{\mathrm{a}}$ \\ ${ }^{a}$ Winogradsky Institute of Microbiology, Research Center of Biotechnology of the Russian Academy of Sciences, Leninskiy Prospect, 33, bld. 2, 119071 Moscow, Russia \\ ${ }^{\mathrm{b}}$ Univ Brest, CNRS, Ifremer, UMR 6197, Laboratoire de Microbiologie des Environnements Extrêmes LM2E, LIA1211, MicrobSea, F-29280, Plouzané, France
}

\section{A R T I C L E I N F O}

\section{Keywords:}

Thermophile

Chemolithoautotroph

Extreme environment

Deep sea

Sulfur disproportionation

Nap complex

\begin{abstract}
A B S T R A C T
Thermosulfuriphilus ammonigenes $\mathrm{ST} 65^{\mathrm{T}}$ is an anaerobic thermophilic bacterium isolated from a deep-sea hydrothermal vent chimney. T. ammonigenes is an obligate chemolithoautotroph utilizing elemental sulfur as an electron donor and nitrate as an electron acceptor with sulfate and ammonium formation. It also is able to grow by disproportionation of elemental sulfur, thiosulfate and sulfite. Here, we present the complete genome sequence of strain $S T 65^{\mathrm{T}}$. The genome consists of a single chromosome of 2,287,345 base pairs in size and has a $\mathrm{G}+\mathrm{C}$ content of $51.9 \mathrm{~mol} \%$. The genome encodes 2172 proteins, 48 tRNA genes, and 3 rRNA genes. Genome analysis revealed a complete set of genes essential to $\mathrm{CO}_{2}$ fixation and gluconeogenesis. Homologs of genes encoding known enzyme systems for nitrate ammonification are absent in the genome of T. ammonigenes assuming unique mechanism for this pathway. The genome of strain $\mathrm{ST} 65^{\mathrm{T}}$ encodes a complete set of genes necessary for dissimilatory sulfate reduction, which are probably involved in sulfur disproportionation and anaerobic oxidation. This is the first reported genome of a bacterium from the genus Thermosulfuriphilus, providing insights into the microbial contribution into carbon, sulfur and nitrogen cycles in the deep-sea hydrothermal vent environment.
\end{abstract}

\section{Introduction}

The deep-sea hydrothermal systems are characterized by darkness, high pressures and steep gradients of physical and chemical parameters formed in mixing zones between hot reduced hydrothermal fluid and cold oxidized ocean water. As water column prevents the penetration of the sunlight, the trophic chains in these ecosystems are based primarily on chemosynthesis with chemolithoautotrophic microorganisms as primary producers. A number of studies have shown the predominance of Proteobacteria, especially Epsilonproteobacteria in deep sea hydrothermal systems, while other bacterial groups like the Aquificales, Thermales, Thermotogales, Deltaproteobacteria, and Thermodesulfobacteriaceae are also often detected (Nakagawa and Takai, 2008; Orcutt et al., 2011; Flores et al., 2012). Most of the cultivated representatives of these taxa are associated with utilization of inorganic sulfur compounds.

The genus Thermosulfuriphilus belongs to a deep lineage in the phylum Thermodesulfobacteria (Slobodkina et al., 2017). Currently, the genus comprises a sole species, T. ammonigenes $\mathrm{ST} 65^{\mathrm{T}}$, an extremely thermophilic, anaerobic, obligately chemolithoautotrophic bacterium that was isolated from a deep-sea hydrothermal vent at the Eastern Lau Spreading Centre in the Pacific Ocean, at a depth of $1870 \mathrm{~m}$. The energy metabolism of $T$. ammonigenes $\mathrm{ST} 65^{\mathrm{T}}$ is mandatorily dependent on the transformations of sulfur compounds. The strain grows due to oxidation of elemental sulfur or thiosulfate coupled to reduction of nitrate with ammonium production. It also grows by disproportionation of sulfur, thiosulfate and sulfite (Slobodkina et al., 2017).

In this study, we analyzed the genome of T. ammonigenes $S T 65^{\mathrm{T}}$, the first sequenced complete genome within the species of genus Thermosulfuriphilus, and highlighted its general metabolic pathways. The availability of the genome sequence will promote the better understanding of the metabolic traits of prokaryotes participating in sulfur, nitrogen and carbon cycles in such unique types of ecosystems as deep-sea hydrothermal vents.

\footnotetext{
* Corresponding author at: Winogradsky Institute of Microbiology, Research Center of Biotechnology of the Russian Academy of Sciences, Moscow, Russia.

E-mail address: gslobodkina@mail.ru (G. Slobodkina).
} 


\section{Data description}

For genomic DNA extraction, the strain was cultivated anaerobically at $65{ }^{\circ} \mathrm{C}$ with elemental sulfur $(5 \mathrm{~g} / \mathrm{L})$ and potassium nitrate $(10 \mathrm{mM})$ as an electron donor and an electron acceptor, respectively. Cells were harvested in the late exponential phase of growth. The DNA was extracted using a FastDNA ${ }^{\mathrm{TM}}$ Spin Kit (MP Biomedicals, USA) according to the manufacturer's instructions. The whole genome was sequenced using the Illumina nanoMiSeq technology (Fasteris, Switzerland) $(2 \times 150$ bp paired-reads, Nano V2 chemistry) generating more than $200 \mathrm{Mb}$ clean data, and using the PacBio Sequel technology (MrDNA, USA). Clean reads from long-reads and short reads sequencing were assembled and circularized using Unicycler v0.4.8-beta assembly pipeline (ttps://github.com/rrwick/Unicycler) (Wick et al., 2017). Average coverage was calculated using BBtools (BBMap - Bushnell B. sourceforge.net/projects/bbmap/) and was about $88 \mathrm{x}$. Gene search and annotation were performed by means of the Rapid Annotation using Subsystem Technology (RAST/SEED v2.0) pipeline (Overbeek et al., 2014), the Integrated Microbial genomes IMG/M v.5.0 analysis system (Chen et al., 2019) and NCBI's (National Center of Biotechnology Information) Prokaryotic Genome Annotation Pipeline (PAGP) (Tatusova et al., 2016). The search and analysis of transposase families was performed by ISSaga web server (Varani et al., 2011). Identification and classification of the CRISPR-Cas system was performed by the CRISPRCas Finder web server (Couvin et al., 2018). The prediction of laterally transferred gene clusters (genomic islands) was performed with the IslandViewer4 web server (Bertelli et al., 2017). Genome visualization was made with the CGView program (Grant and Stothard, 2008).

The general features of T. ammonigenes strain $\mathrm{ST} 65^{\mathrm{T}}$ and the genome sequencing information are summarized in Table 1.

The complete genome of strain $\mathrm{ST} 65^{\mathrm{T}}$ consisted of a single circular chromosome with a total length of 2,287,345 bp and a G + C content of $51.9 \mathrm{~mol} \%$. No plasmids were detected (Fig. 1). CheckmM v1.1.2 estimated the genome to be $99.5935 \%$ complete based on the presence of default single-copy marker genes (1 marker was missing) and hypothetical contamination to be $1.6260 \%$. Annotation with PGAP resulted in prediction of 2236 genes, 2172 of which are protein-coding sequences (CDSs) that cover about $97 \%$ of the entire genome. Genome also contained one operon of 5S, $16 \mathrm{~S}$ and $23 \mathrm{~S}$ rRNA genes and 48 tRNA genes for all 20 standard amino acids. No CRISPR loci were found.

Analysis of the COG (Clusters of Orthologous Genes) functional categories was performed with the eggNOG-Mapper (v.5.0) (HuertaCepas et al., 2019). Majority of the CDSs (95.3\%) could be assigned to at least one COG group. The main predicted COG categories (encompassing more than $100 \mathrm{CDSs}$ ) were energy production and conversion (11.9\%); translation, ribosomal structure and biogenesis (7.97\%); cell wall/membrane/envelope biogenesis (7.23\%); amino acid transport and metabolism (6.92\%); signal transduction mechanisms $(6.81 \%)$; replication, recombination and repair (5.97\%) and coenzyme transport and metabolism $(5.56 \%)$.

A large number of various transposases and integrases could facilitate the transfer of adaptive genes between different microbial species, and thus contribute to the diversity of deep-sea bacteria. The search and analysis of transposases revealed the presence of 10 insertion sequences (IS) belonging to 4 different IS families (IS3_ssgr_IS407, IS256, IS3_ssgr_IS150 and IS630). These sequences contained putative genes of 4 transposases and 10 integrases that according to Pfam database belonged to diverse protein families (Table 2).

The prediction of laterally transferred genes showed that the $T$. ammonigenes $\mathrm{ST}^{\mathrm{T}} 5^{\mathrm{T}}$ genome possesses 5 genomic islands (GI) of $124.3 \mathrm{~kb}$ total length. The vast majority of the genes located on the genomic islands encode proteins annotated as hypothetical proteins. Meanwhile, one of genomic islands carried genes encoding ribosomal proteins and also genes involved in dissimilatory sulfate reduction (sat, $a p r A B$ and $q m o A B C$ ) (Fig. 1).
Table 1

General features and genome sequencing information for Thermosulfuriphilus ammonigenes $\mathrm{ST}^{\mathrm{T}} \mathrm{5}^{\mathrm{T}}$ according to MIGS recommendations.

\begin{tabular}{|c|c|}
\hline Item & Description \\
\hline \multicolumn{2}{|l|}{ Investigation } \\
\hline Submitted to INSDC & GenBank: CP048877 \\
\hline Investigation type & Bacteria \\
\hline Project name & $\begin{array}{l}\text { Thermosulfuriphilus ammonigenes type strain } \\
\text { ST65 genome sequencing }\end{array}$ \\
\hline NCBI BioProject & Accession: PRJNA606893 ID: 606893 \\
\hline NCBI BioSample & Accession: SAMN14116118 ID: 14116118 \\
\hline Geographic location (latitude & $21^{\circ}$ \\
\hline and longitude) & $\begin{array}{l}59^{\prime} 35^{\prime \prime} \mathrm{S}, 176^{\circ} \\
34^{\prime} 06^{\prime \prime} \mathrm{W}\end{array}$ \\
\hline $\begin{array}{l}\text { Geographic location (country } \\
\text { and/or sea, region) }\end{array}$ & $\begin{array}{l}\text { Eastern Lau Spreading Centre, south-west } \\
\text { Pacific Ocean }\end{array}$ \\
\hline Collection date & June 2009 \\
\hline Environment (biome) & $\begin{array}{l}\text { marine hydrothermal vent biome } \\
\text { ENVO:01000030 }\end{array}$ \\
\hline Environment (feature) & marine hydrothermal vent ENVO:01000122 \\
\hline Environment (material) & $\begin{array}{l}\text { marine hydrothermal vent chimney } \\
\text { ENVO:01000129 }\end{array}$ \\
\hline Depth & $1870 \mathrm{~m}$ \\
\hline \multicolumn{2}{|l|}{ General features } \\
\hline Classification & $\begin{array}{l}\text { Domain Bacteria } \\
\text { Phylum Thermodesulfobacteria } \\
\text { Class Thermodesulfobacteria } \\
\text { Order Thermodesulfobacteriales } \\
\text { Family Thermodesulfobacteriaceae } \\
\text { Genus Thermosulfuriphilus } \\
\text { Species: Thermosulfuriphilus ammonigenes }\end{array}$ \\
\hline Gram stain & Negative \\
\hline Cell shape & Rod \\
\hline Motility & non-motile \\
\hline Growth temperature range & $\begin{array}{l}\text { Thermophilic, optimum at } 65^{\circ} \\
\text { C }\end{array}$ \\
\hline Relationship to oxygen & Obligate anaerobe \\
\hline Trophic level & Chemolithoautotroph \\
\hline Biotic relationship & free-living \\
\hline Isolation and growth conditions & DOI https://doi.org/10.1099/ijsem.0.002142 \\
\hline \multicolumn{2}{|l|}{ Sequencing } \\
\hline Sequencing platform & Illumina MiSeq + PacBio Sequel (hybrid) \\
\hline Assembler & Unicycler v 0.4.8-beta \\
\hline Finishing strategy & complete \\
\hline Method reads & Hybrid \\
\hline Contig number & 1 \\
\hline N50 & $2,287,345$ \\
\hline Genome coverage & $88 x$ \\
\hline \multicolumn{2}{|l|}{ Genomic features } \\
\hline Genome size (bp) & $2,287,345$ \\
\hline $\mathrm{G}+\mathrm{C}$ content $(\mathrm{mol} \%)$ & 51.9 \\
\hline Number of genes & 2236 \\
\hline Protein coding genes & 2172 \\
\hline Genes with COGs & 1908 \\
\hline Number of RNAs & 55 \\
\hline rRNAs & $1,1,1(5 S, 16 S, 23 S)$ \\
\hline tRNAs & 48 \\
\hline
\end{tabular}

The whole-genome sequence data were generally consistent with the main metabolic features experimentally demonstrated in strain ST65 ${ }^{\mathrm{T}}$ (Slobodkina et al., 2017). The genome of strain ST65 ${ }^{\mathrm{T}}$ possessed the genes essential for the Wood-Ljungdahl (the reductive acetyl-CoA) pathway for the fixation of $\mathrm{CO}_{2}$. In consistence with the inability of ST65 ${ }^{\mathrm{T}}$ to utilize organic substances, the tricarboxylic acid cycle (TCA) was found to be incomplete (4 enzymes out of 9 were missing). The genome contained all genes for glycolysis (Embden-Meyerhof pathway) which obviously operated in the reverse direction for gluconeogenesis. The ability to use nitrate as an electron acceptor is enabled by the presence of an operon napMADGH encoding periplasmic Nap-type nitrate reductase. The reduction of the produced nitrite to ammonium does not proceed via the canonical Nrf system because the gene, encoding the key enzyme of this pathway (i.e., pentaheme cytochrome $c$ 


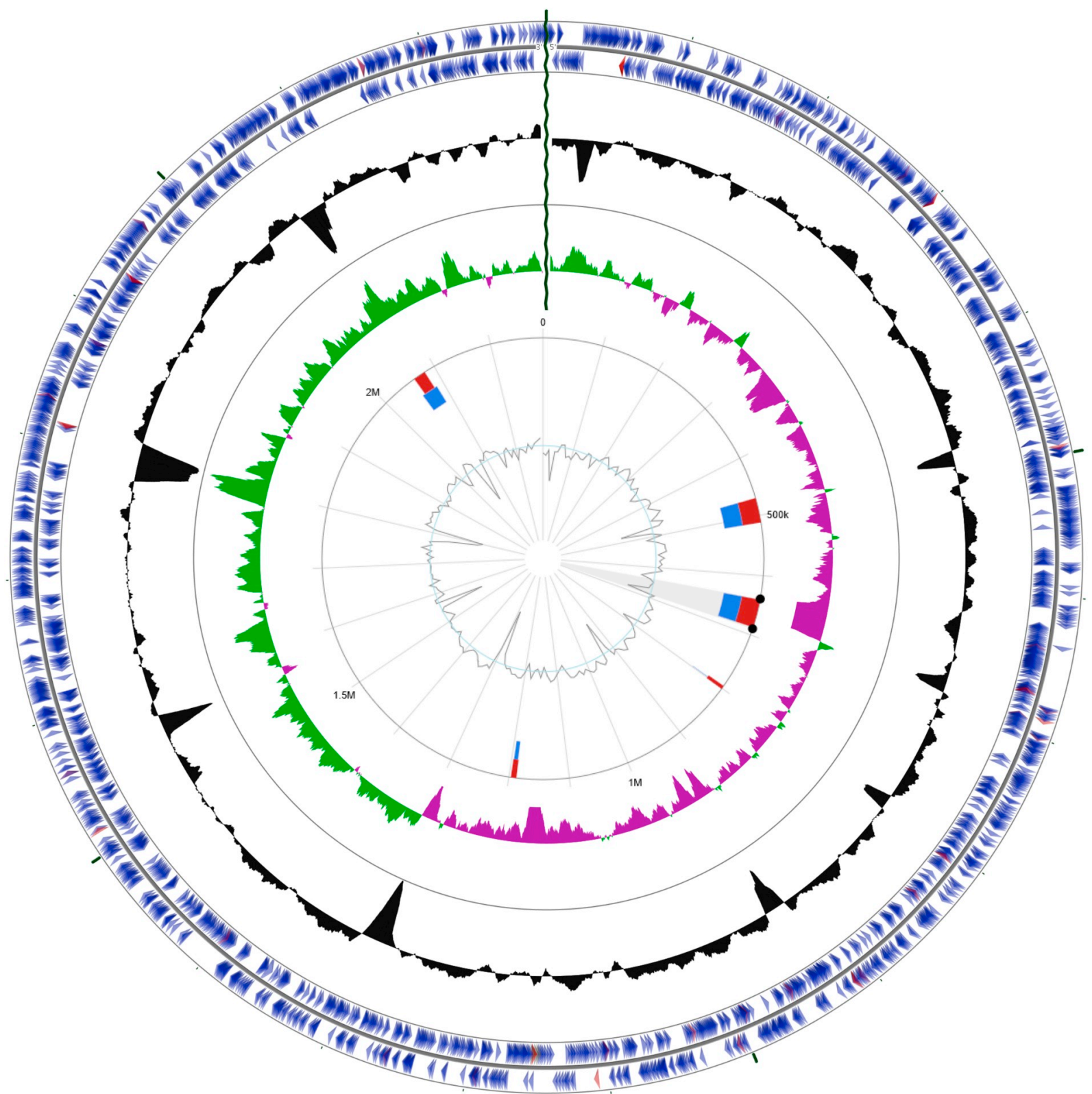

Fig. 1. Schematic representation of the Thermosulfuriphilus ammonigenes $\mathrm{ST} 65^{\mathrm{T}}$ genome. Labeling from the outside to the center is as follows: circle 1, genes on the forward strand; circle 2, genes on reverse strand (tRNAs pink, rRNAs lilac); circle 3, G + C content; circle 4, G + C skew. Genomic islands are shown as red-and-blue trapezes, GI carrying sulfate reduction genes highlighted in black circles. (For interpretation of the references to colour in this figure legend, the reader is referred to the web version of this article.)

nitrite reductase NrfA), was not found in the genome. Yet, the genome of strain $\mathrm{ST} 65^{\mathrm{T}}$ contains genes of hydroxylamine oxidoreductases (Hao) and hydroxylamine reductase (Hcp). Thus, the Nrf complex in T. ammonigenes could be replaced by an ammonification pathway based on Hao and Hcp enzymes as it has been proposed for several other marine bacteria (Hanson et al., 2013; Slobodkina et al., 2017a; Slobodkin et al., 2019).

Sulfur cycle is of a great importance in the deep-sea environments. It is notably the case at deep-sea hydrothermal vents where the reactions of $\mathrm{CO}_{2}$ fixation, linkage to organic matter metabolism and remineralization to $\mathrm{CO}_{2}$ involve especially the oxidation or reduction of inorganic sulfur species of different redox states. Homologs of genes encoding known enzyme systems of reduced sulfur compounds oxidation such as sulfide: quinone oxidoreductase (SQR), sulfite oxidizing enzyme (SOE), sulfur oxidizing (Sox) enzyme complex or sulfur oxygenase/reductase (SOR) were absent in genome of T. ammonigenes. The genome of strain $\mathrm{ST} 65^{\mathrm{T}}$ encodes a complete set of genes necessary for dissimilatory sulfate reduction although the ability of this microorganism to grow by sulfate respiration was not revealed in laboratory experiments (Slobodkina et al., 2017). Probably, the sulfate reduction pathway in this bacterium is involved in disproportionation of sulfur compounds as it was assumed earlier for Desulfocapsa sulfoexigens and Thermosulfurimonas dismutans (Frederiksen and Finster, 2003; Mardanov et al., 2016). Some of these genes also can be used to oxidize sulfur compounds during growth with $S^{0}$ or thiosulfate and nitrate as it was shown for phototrophic sulfur bacteria (Frigaard and Dahl, 2009). The detection of sulfate reducing genes on GI indicates the contribution of mobile elements in the adaptation of bacteria to the environment and in active participation in the sulfur cycle.

In conclusion, the genomic analysis of T. ammonigenes $S T 65^{\mathrm{T}}$ has revealed that despite the ability of the strain to grow by sulfur oxidation coupled to nitrate ammonification, the genes encoding the canonical 
Table 2

Mobile elements in the genome of Thermosulfuriphilus ammonigenes ST65 ${ }^{\mathrm{T}}$.

\begin{tabular}{llll}
\hline Gene ID & Gene product & Pfam ID & $\begin{array}{l}\text { Number of } \\
\text { genes }\end{array}$ \\
\hline $\begin{array}{c}\text { QIJ70900 (2 copies) } \\
\text { QIJ72367 (2 } \\
\text { copies) }\end{array}$ & Integrase core domain & pfam13358 & 5 \\
$\begin{array}{l}\text { QIJ72678 } \\
\text { QIJ71194 }\end{array}$ & & \\
QIJ71591 & Phage integrase family & pfam00589 & 2 \\
$\begin{array}{l}\text { QIJ71463 } \\
\text { QIJ71806 }\end{array}$ & Phage integrase & pfam13495 & 1 \\
QIJ72599 & Transposase, Helix-turn- & pfam01527 & 3 \\
QIJ72601 & helix domains & & \\
QIJ71807 & Integrase core domain & pfam00665 & 2 \\
QIJ72907 & Transposase, Mutator & pfam00872 & 1 \\
QIJ71809 & family & & \\
& & & \\
\hline
\end{tabular}

enzyme systems for these pathways such as SQR, SOE, Sox, SOR and Nrf, are absent. Conversely, the presence of all genes necessary for dissimilatory sulfate reduction does not provide the ability to grow due to sulfate reduction. These genes are apparently involved in disproportionation and oxidation of reduced sulfur compounds. In accordance with the fact that $T$. ammonigenes is an obligate lithoautotroph its genome contains genes involved in $\mathrm{CO}_{2}$ fixation, gluconeogenesis and incomplete set of genes participating in TCA cycle.

\section{Genome sequence accession numbers}

The genome sequence of T. ammonigenes $\mathrm{ST} 65^{\mathrm{T}}$ has been deposited in DDBJ/ENA/GenBank under the accession number CP048877. The BioSample data is available in the NCBI BioSample database (http:// www.ncbi.nlm.nih.gov/biosample/) under the accession number SAMN14116118. The BioProject data is available in the NCBI BioProject database (https://www.ncbi.nlm.nih.gov/bioproject/) under the accession number PRJNA606893. The strain is available in the German Collection of Microorganisms and Cell Cultures (DSMZ) and All-Russian Collection of Microorganisms (VKM) under the accession numbers DSM $102941^{\mathrm{T}}$ and VKM B-2855 ${ }^{\mathrm{T}}$.

\section{Acknowledgement}

This research was funded by the Russian Foundation for Basic Research, grant number 18-54-15008, by the Ministry of Science and Higher Education of the Russian Federation, by the French-Russian collaborative project (CNRS/RFBR) Neptune (PRC Russie 2017 $\mathrm{n}^{\circ} 281295$ ), and by the LIA 1211 MicrobSea.

\section{Declaration of Competing Interests}

The authors declare that they have no known competing financial interests or personal relationships that could have appeared to influence the work reported in this paper.

\section{References}

Bertelli, C., Laird, M.R., Williams, K.P., Lau, B.Y., Hoad, G., Winsor, G.L., Brinkman, F.S., Brinkman, F.S.L., 2017. IslandViewer 4: expanded prediction of genomic islands for larger-scale datasets. Nucleic Acids Res. 45, W30-W35. https://doi.org/10.1093/ nar/gkx343.

Chen, I.-M.A., Chu, K., Palaniappan, K., Pillay, M., Ratner, A., Huang, J., Huntemann, M., Varghese, N., White, J.R., Seshadri, R., Smirnova, T., Kirton, E., Jungbluth, S.P., Woyke, T., Eloe-Fadrosh, E.A., Ivanova, N.N., Kyrpides, N.C., 2019. IMG/M v.5.0: an integrated data management and comparative analysis system for microbial genomes and microbiomes. Nucleic Acids Res. 47, 666-677. https://doi.org/10.1093/nar/ gky901.

Couvin, D., Bernheim, A., Toano-Nioche, C., Touchon, M., Michalik, J., Néron, B., Rocha, E.P.C., Vergnaud, G., Gautheret, D., Pourcel, C., 2018. CRISPRCasFinder, an update of CRISRFinder, includes a portable version, enhanced performance and integrates search for Cas proteins. Nucleic Acids Res. 46, W246-W251. https://doi.org/10. 1093/nar/gky425.

Flores, G.E., Shakya, M., Meneghin, J., Yang, Z.K., Seewald, J.S., Geoff Wheat, C., Podar, M., Reysenbach, A.L., 2012. Inter-field variability in the microbial communities of hydrothermal vent deposits from a back-arc basin. Geobiology. 10, 333-346. https:// doi.org/10.1111/j.1472-4669.2012.00325.x.

Frederiksen, T.M., Finster, K., 2003. Sulfite-oxido-reductase is involved in the oxidation of sulfite in Desulfocapsa sulfoexigens during disproportionation of thiosulfate and elemental sulfur. Biodegradation 14, 189-198. https://doi.org/10.1023/ A:1024255830925.

Frigaard, N.-U., Dahl, C., 2009. Sulfur metabolism in phototrophic sulfur bacteria. Adv. Microb. Physiol. 54, 103-200. https://doi.org/10.1016/S0065-2911(08)00002-7.

Grant, J.R., Stothard, P., 2008. The cgview server: a comparative genomics tool for circular genomes. Nucleic Acids Res. 36, W181-W184. https://doi.org/10.1093/nar/ gkn179.

Hanson, T.E., Campbell, B.J., Kalis, K.M., Campbell, M.A., Klotz, M.G., 2013. Nitrate ammonification by Nautilia profundicola AmH: experimental evidence consistent with a free hydroxylamine intermediate. Front. Microbiol. 4, 180. https://doi.org/10. 3389/fmicb.2013.00180.

Huerta-Cepas, J., Szklarczyk, D., Heller, D., Hernández-Plaza, A., Forslund, S.K., Cook, H., Mende, D.R., Letunic, I., Rattei, T., Jensen, L.J., von Mering, C., Peer, Bork P., 2019. eggNOG 5.0: a hierarchical, functionally and phylogenetically annotated orthology resource based on 5090 organisms and 2502 viruses. Nucleic Acids Res. 47, D309-D314. https://doi.org/10.1093/nar/gky1085.

Mardanov, A.V., Beletsky, A.V., Kadnikov, V.V., Slobodkin, A.I., Ravin, N.V., 2016. Genome analysis of Thermosulfurimonas dismutans, the first thermophilic sulfur-disproportionating bacterium of the phylum Thermodesulfobacteria. Front. Microbiol. 7, 950. https://doi.org/10.3389/fmicb.2016.00950.

Nakagawa, S., Takai, K., 2008. Deep-sea vent chemoautotrophs: diversity, biochemistry and ecological significance: chemoautotrophy in deep-sea vents. FEMS Microbiol. Ecol. 65, 1-14. https://doi.org/10.1111/j.1574-6941.2008.00502.x.

Orcutt, B.N., Sylvan, J.B., Knab, N.J., Edwards, K.J., 2011. Microbial ecology of the dark ocean above, at, and below the seafloor. Microbiol. Mol. Biol. Rev. 75, 361-422. https://doi.org/10.1128/MMBR.00039-10.

Overbeek, R., Olson, R., Pusch, G.D., Olsen, G.J., Davis, J.J., Disz, T., Edwards, R.A., Gerdes, S., Parrello, B., Shukla, M., Vonstein, V., Wattam, A.R., Xia, F., Stevens, R., 2014. The SEED and the rapid annotation of microbial genomes using subsystems technology (RAST). Nucleic Acids Res. 42, D206-D214. https://doi.org/10.1093/ nar/gkt1226.

Slobodkin, A., Slobodkina, G., Allioux, M., Alain, K., Jebbar, M., Shadrin, V., Kublanov, I., Toshchakov, S., Bonch-Osmolovskaya, E., 2019. Genomic insights into the carbon and energy metabolism of a thermophilic deep-sea bacterium Deferribacter autotrophicus revealed new metabolic traits in the phylum Deferribacteres. Genes. 10, 849. https://doi.org/10.3390/genes10110849.

Slobodkina, G.B., Reysenbach, A.L., Kolganova, T.V., Novikov, A.A., BonchOsmolovskaya, E.A., Slobodkin, A.I., 2017. Thermosulfuriphilus ammonigenes gen. nov., sp. nov., a thermophilic, chemolithoautotrophic bacterium capable of respiratory ammonification of nitrate with elemental sulfur. Int. J. Syst. Evol. Microbiol. 67, 3474-3479. https://doi.org/10.1099/ijsem.0.002142.

Slobodkina, G.B., Mardanov, A.V., Ravin, N.V., Frolova, A.A., Chernyh, N.A., BonchOsmolovskaya, E.A., Slobodkin, A.I., 2017a. Respiratory ammonification of nitrate coupled to anaerobic oxidation of elemental sulfur in deep-sea autotrophic thermophilic bacteria. Front. Microbiol. 8, 87. https://doi.org/10.3389/fmicb.2017.00087.

Tatusova, T., DiCuccio, M., Badretdin, A., Chetvernin, V., Nawrocki, E.P., Zaslavsky, L., Lomsadze, A., Pruitt, K.D., Borodovsky, M., Ostell, J., 2016. NCBI prokaryotic genome annotation pipeline. Nucleic Acids Res. 44, 6614-6624. https://doi.org/10. 1093/nar/gkw569.

Varani, A.M., Siguier, P., Gourbeyre, E., Charneau, V., Chandler, M., 2011. ISsaga is an ensemble of web-based methods for high throughput identification and semi-automatic annotation of insertion sequences in prokaryotic genomes. Genome Biol. 12, R30. https://doi.org/10.1186/gb-2011-12-3-r30.

Wick, R.R., Judd, L.M., Gorrie, C.L., Holt, K.E., 2017. Unicycler: resolving bacterial genome assemblies from short and long sequencing reads. PLoS Comput. Biol. 13, e1005595. https://doi.org/10.1371/journal.pcbi.1005595. 